\title{
Correlation between polymorphisms of nicotine acetylcholine acceptor subunit CHRNA3 and lung cancer susceptibility
}

\author{
BO SHEN ${ }^{1}$, MEI-QI SHI ${ }^{1}$, MA-QING ZHENG ${ }^{2}$, SAI-NAN HU $^{1}$, JIA CHEN $^{1}$ and JI-FENG FENG ${ }^{1}$ \\ ${ }^{1}$ Department of Medical Oncology, Jiangsu Cancer Hospital, Jiangsu 210009; ${ }^{2}$ Department of Pharmacology, \\ Drug Research Institute of Jiangsu Province, Nanjing University of Technology, Nanjing, Jiangsu 211816, P.R. China
}

Received May 17, 2012; Accepted September 20, 2012

DOI: $10.3892 / \mathrm{mmr} .2012 .1101$

\begin{abstract}
Both environmental and genetic factors participate in the pathogenesis of lung cancer. The aim of this study was to explore the association between CHRNA3 polymorphisms of the nicotinic acetylcholine receptor gene and lung cancer risk in a hospital-based, case-controlled study. Single nucleotide polymorphisms (SNPs) in CHRNA3 rs3743073 (A>G) were determined using the TaqMan-MGB probe technique in 600 lung cancer cases and 600 normal controls. The differences in genotype and allele frequency were compared between groups and their association with lung cancer. The genotype frequency of rs3743073 (A>G) demonstrated Hardy-Weinberg equilibrium $(\mathrm{P}<0.05)$. The genotype and allele frequencies were significantly different between the cancer and control groups $(\mathrm{P}<0.05)$. Compared with patients with the TT genotype, lung cancer incidence was increased in patients with the TG and GG genotypes (OR=1.68; 95\% CI, 1.30-2.19; $\mathrm{P}<0.05$; $\mathrm{OR}=1.30 ; 95 \% \mathrm{CI}, 1.05-1.61 ; \mathrm{P}<0.05$, respectively). Patients with rs3743073G variant alleles (TG and GG) were at greater risk $(\mathrm{OR}=0.65 ; 95 \% \mathrm{CI}, 0.50-0.84 ; \mathrm{P}<0.05)$ of developing lung cancer. Increased risk associated with rs3743073G variant alleles was observed in male smokers over the age of $60(\mathrm{P}<0.05)$. In this cohort, the CHRNA3 gene rs3743073G variant genotype significantly increased lung cancer risk, especially in male smokers over the age of 60 .
\end{abstract}

\section{Introduction}

Lung cancer is one of the most common malignant tumors in humans and is the most common cause of cancer-related mortality (1). For example, the United States had 219,440 new cases of lung cancer and 159,390 mortalities in 2009. China had 483,040 new cases of lung cancer and 420,411 mortalities

Correspondence to: Dr Ji-Feng Feng, Department of Medical Oncology, Jiangsu Cancer Hospital, No. 42 Bai Zi Ting, Nanjing, Jiangsu 210009, P.R. China

E-mail: fengjf0518@126.com

Key words: lung cancer, nicotinic acetylcholine receptors, CHRNA3 gene, single nucleotide polymorphisms between 2004 and 2005 (2). Lung cancer is the main health threat in China, and greater research focus is needed towards the prevention and control of this disease.

Epidemiology studies attribute the occurrence of lung cancer to exposure to environmental risk factors. Chronic smoking, occupational exposure, air pollution and other factors are considered to be causes of lung cancer $(3,4)$. Smoking causes over $80 \%$ of lung cancer cases (5). However, less than $20 \%$ of smokers develop lung cancer. The reasons for varied cancer susceptibility among smokers are unknown. Molecular epidemiology investigates the correlation between genetic factors, environmental factors and lung cancer incidence. Relevant clinical histories, such as COPD (6), and genetic factors, such as gene mutations, are correlated with lung cancer incidence. A previous meta-analysis (7) on family history and lung cancer showed that risk was increased with lung cancer occurrence within three generations compared with those without such a family history (8). This finding suggests that individual genetic background is closely correlated with lung cancer susceptibility.

Smoking is by far the main contributor to lung cancer incidence. Cigarette smoke contains numerous carcinogens, including tar and benzopyrene (9). These carcinogens activate signaling pathways that affect cell growth, differentiation and apoptosis. At present, nicotine is the main addictive component in cigarettes, and opinions differ about whether nicotine directly causes cancer. Nicotine is responsible for the dependence-forming properties of tobacco smoking and this addiction greatly exacerbates the cumulative health dangers of tobacco (10).

Nicotine acts on specific nicotinic acceptors in vivo. Activation of members of the nicotine receptor family (CHRNA) by nicotine activates Akt signaling molecules to protect tumor cells from 'programmed cell death', or apoptosis. Avoiding apoptosis is a key early event in cancer initiation (11). CHRNA expression in a core region of the brain is closely correlated with nicotine addiction $(12,13)$. Nicotine receptors are present in lung epithelial cells and are involved in signal transduction that promotes cell proliferation and cancer metastasis (14-16).

Genome-wide association studies of lung cancer in Europe and the United States have identified sites on the acetylcholine receptor subunit that alter genetic susceptibility for lung cancer (17-19). In vivo, the acetylcholine receptor is activated 
by carcinogenic agents in tobacco, such as nicotine and nitrosamine. Nicotine-activated acetylcholine receptor promotes cell tumorigenic transformation, angiogenesis and cell growth, thereby promoting tumor development (20).

Allelic variation in one site in the acetylcholine receptor subunit CHRNA3 is closely associated with lung cancer. The frequency of this allele variation is higher in Asian populations (21). Therefore, it is necessary to explore polymorphisms associated with lung cancer susceptibility as affected by several demographic and environmental variables. This study aims to disclose the correlation between polymorphisms in CHRNA3 (rs3743073) and lung cancer in a cohort using a case-control association study.

\section{Subjects and methods}

Research subjects. Samples from cases of primary lung cancer $(n=600)$ were collected from Jiangsu Cancer Hospital of Nanjing city between January 2008 and February 2011. Samples from a normal control population $(n=600)$ included 444 males and 156 females. All patients in the cancer patient group had confirmed pathological diagnosis of lung cancer without other tumor disease histories. Control group subjects were randomly collected from healthy individuals during the same time period in one geographic region and without any tumor history. Subjects in the two groups were matched by age and gender. A peripheral venous blood sample (5 cc, sodium heparin anticoagulant) was obtained from all individuals after obtaining signed informed consent. This study was approved by the ethics committee of Jiangsu Cancer Hospital, Nanjing, China.

Epidemiology survey. The epidemiology survey included age, gender, individual history of occupational exposure, disease history, family history of tumor and nutrition status. Individual smoking status included smoking or non-smoking, daily number of cigarettes smoked, years of smoking and smoking situation for the primary residence. The definition of non-smokers was those who smoke $<1$ cigarette per day and had a cumulative smoking time of $<1$ year in a lifetime. Those who had quit smoking more than 1 year previously were considered non-smokers. Informed consent was obtained from subjects or from their family/caregiver.

DNA extraction. Genomic DNA was extracted from $2 \mathrm{ml}$ of peripheral blood using the $0.1-20 \mathrm{ml}$ blood genomic DNA extraction system (DP319-01, Tiangen Biotech Co. Ltd., Beijing, China).

Genotyping. The genome sequence of $\operatorname{rs} 3743073(\mathrm{~T}>\mathrm{G})$ in CHRNA3 was obtained by referencing a single nucleotide polymorphism (SNP) database (http://www.ncbi.nlm.nih.gov/ snp). The CHRNA3 SNP genotype of $\operatorname{rs} 3743073$ (T>G) was detected using the TaqMan-MGB probe technology (Applied Biosystems, Foster City, CA, USA). Furthermore, the experimental results were separately observed and recorded by two researchers.

Statistical methods. SPSS 17.0 statistical software was used for statistical analysis. The $t$-test was used to compare age between
Table I. Comparison of basic characteristics between cancer and control groups.

\begin{tabular}{|c|c|c|c|c|}
\hline Variable & $\begin{array}{l}\text { Cases } \\
(\mathrm{n}=600)\end{array}$ & $\begin{array}{l}\text { Controls } \\
(\mathrm{n}=600)\end{array}$ & $\begin{array}{l}\mathrm{t} \text {-test/ } \\
\chi^{2} \text { test }^{\mathrm{a}}\end{array}$ & P-value \\
\hline Age $($ mean $\pm \mathrm{SD})$ & $59.9 \pm 5.30$ & $60.4 \pm 5.40$ & 1.531 & 0.126 \\
\hline \multicolumn{5}{|l|}{ Gender (\%) } \\
\hline Male & 466 (77.7) & $444(74.0)$ & 2.201 & 0.138 \\
\hline Female & $134(22.3)$ & $156(26.0)$ & & \\
\hline \multicolumn{5}{|l|}{$\begin{array}{l}\text { Smoking } \\
\text { status }(\%)\end{array}$} \\
\hline Non-smokers & $248(41.3)$ & $308(51.3)$ & 12.065 & 0.001 \\
\hline Smokers & $352(58.7)$ & $292(48.7)$ & & \\
\hline \multicolumn{5}{|l|}{$\begin{array}{l}\text { Family history } \\
\text { of cancer }(\%)\end{array}$} \\
\hline No & $524(87.3)$ & $542(90.3)$ & 2.722 & 0.099 \\
\hline Yes & $76(12.7)$ & $58(9.7)$ & & \\
\hline
\end{tabular}

${ }^{a}$-test for age, $\chi^{2}$ test for other variables.

the two groups, and the $\chi^{2}$ test was adopted to compare gender, smoking, tumor family history, genotypes and allele frequency. The correlation between gene polymorphism and the risk of lung cancer was analyzed using the odds ratio (OR), which was obtained by unconditional logistic regression analysis and a 95\% confidence interval. The above analysis was performed with a two-sided test; the $\alpha$ level was 0.05 , and $\mathrm{P}<0.05$ was considered to indicate a statistically significant difference.

\section{Results}

Table I shows the distribution of age, gender, smoking status and tumor family history. The median age for the cancer patient group was $59.9 \pm 5.3$ years and $60.4 \pm 5.4$ years for the control group. Lung cancer was more frequently observed in males than females, with a ratio of approximately $3: 1$. The percentage of smokers in the cancer patient group was higher than that of the control (58.7 vs. $48.7 \%$ ). There was no significant difference in age, gender distribution or tumor family history between the cancer patient and control groups $(\mathrm{P}>0.05)$, while there was a significant difference in smoking history between the cancer patient and control groups $(\mathrm{P}<0.05)$.

Genotypes and allele frequency. Table II shows that all rs3743073 allele frequencies in the control group were in compliance with Hardy-Weinberg equilibrium $(\mathrm{P}>0.05)$, therefore, the genotype frequencies in all sites were in balance. The difference between the genotype frequency at rs3743073 (T>G) sites and allele frequency was statistically significant $(\mathrm{P}<0.05)$.

Genotype frequencies and lung cancer. Unconditional logistic regression analysis showed (Table III) that the incidence of lung cancer for patients with genotype TG increased by 1.68-fold relative to patients with the genotype TT $(95 \% \mathrm{CI}$, 1.30-2.19; $\mathrm{P}=0.01$ ). The incidence of lung cancer for patients with genotype GG increased by 1.30 times (95\% CI, 1.05-1.61; 
Table II. Comparison of genotype and allele frequencies between cancer and control groups, no. (\%).

\begin{tabular}{|c|c|c|c|c|c|c|}
\hline \multirow[b]{2}{*}{ Group } & \multirow[b]{2}{*}{ No. } & \multicolumn{3}{|c|}{ Genotype frequency } & \multicolumn{2}{|c|}{ Allele frequency } \\
\hline & & $\mathrm{TT}$ & TG & GG & A & G \\
\hline Case & 600 & $124(20.7)$ & $258(43.0)$ & $218(36.3)$ & $506(96.2)$ & $694(3.8)$ \\
\hline Control & 600 & $186(31.0)$ & $291(48.5)$ & $123(20.5)$ & $663(98.3)$ & $537(1.8)$ \\
\hline Total & & $310(25.8)$ & $549(45.8)$ & $341(28.4)$ & $2333(97.2)$ & $67(2.8)$ \\
\hline$\chi^{2}$ test & & & 40.850 & & 9.596 & \\
\hline P-value & & & 0.001 & & 0.002 & \\
\hline
\end{tabular}

Table III. Association between genotype frequency and risk of lung cancer.

\begin{tabular}{|c|c|c|c|c|c|}
\hline Variable & Genotype & $\begin{array}{c}\text { Cases } \\
\text { no. }(\%)\end{array}$ & $\begin{array}{l}\text { Controls } \\
\text { no. }(\%)\end{array}$ & OR $(95 \%$ CI $)$ & P-value \\
\hline \multirow[t]{4}{*}{ Total } & TT & $124(20.7)$ & $186(31.0)$ & Ref. & \\
\hline & TG & $258(43.0)$ & $291(48.5)$ & $1.68(1.30-2.19)$ & 0.001 \\
\hline & GG & $218(36.3)$ & $123(20.5)$ & $1.30(1.05-1.61)$ & 0.017 \\
\hline & $\mathrm{TG}+\mathrm{GG}$ & $476(79.3)$ & $414(69.0)$ & $0.65(0.50-0.84)$ & 0.001 \\
\hline \multirow[t]{4}{*}{$\leq 60$ years old } & TT & 96 (29.9) & $86(29.3)$ & Ref. & \\
\hline & TG & $143(44.5)$ & $148(50.3)$ & $0.97(0.69-1.37)$ & 0.859 \\
\hline & GG & $82(25.5)$ & $60(20.4)$ & $1.12(0.83-1.51)$ & 0.457 \\
\hline & $\mathrm{TG}+\mathrm{GG}$ & $225(70.1)$ & $208(70.7)$ & $0.79(0.54-1.16)$ & 0.231 \\
\hline \multirow[t]{4}{*}{$>60$ years old } & $\mathrm{TT}$ & $28(10.0)$ & $100(32.7)$ & Ref. & \\
\hline & TG & $115(41.2)$ & $143(46.7)$ & $4.35(2.75-6.88)$ & 0.001 \\
\hline & GG & $136(48.7)$ & $63(20.6)$ & $1.52(1.12-2.06)$ & 0.008 \\
\hline & TG+GG & $251(90.0)$ & $206(67.3)$ & $0.56(0.40-0.80)$ & 0.001 \\
\hline \multirow[t]{4}{*}{ Male } & TT & $80(17.2)$ & $146(32.9)$ & Ref. & \\
\hline & TG & $189(40.6)$ & 204 (45.9) & $2.36(1.73-3.23)$ & 0.001 \\
\hline & GG & $197(42.3)$ & $94(21.2)$ & $1.40(1.09-1.79)$ & 0.008 \\
\hline & $\mathrm{TG}+\mathrm{GG}$ & $386(82.8)$ & $298(67.1)$ & $0.62(0.46-0.83)$ & 0.001 \\
\hline \multirow[t]{4}{*}{ Female } & TT & $44(32.8)$ & $40(25.6)$ & Ref. & \\
\hline & TG & $69(51.5)$ & $87(55.8)$ & $0.71(0.42-1.17)$ & 0.179 \\
\hline & GG & $21(15.7)$ & $29(18.6)$ & $0.98(0.64-1.49)$ & 0.918 \\
\hline & $\mathrm{TG}+\mathrm{GG}$ & $90(67.2)$ & $116(74.4)$ & $1.07(0.57-2.00)$ & 0.829 \\
\hline \multirow[t]{4}{*}{ Non-smoker } & TT & 48 (19.4) & $48(15.6)$ & Ref. & \\
\hline & TG & $123(49.6)$ & $183(59.4)$ & $0.77(0.50-1.20)$ & 0.243 \\
\hline & GG & $77(31.0)$ & $77(25.0)$ & $1.14(0.85-1.54)$ & 0.368 \\
\hline & $\mathrm{TG}+\mathrm{GG}$ & $200(80.6)$ & $260(84.6)$ & $0.77(0.53-1.11)$ & 0.160 \\
\hline \multirow[t]{4}{*}{ Smoker } & $\mathrm{TT}$ & $76(21.6)$ & $138(47.3)$ & Ref. & \\
\hline & TG & $135(38.4)$ & $108(37.0)$ & $3.25(2.31-4.58)$ & 0.001 \\
\hline & GG & $141(40.1)$ & $46(15.8)$ & $1.43(1.04-1.98)$ & 0.028 \\
\hline & $\mathrm{TG}+\mathrm{GG}$ & $276(78.4)$ & $154(52.7)$ & $0.59(0.40-0.86)$ & 0.007 \\
\hline
\end{tabular}

$\mathrm{P}=0.017$ ) compared with the patients with the genotype TT. The incidence of lung cancer for patients with rs3743073G (TG and GG) increased by 0.65 times (95\% CI, 0.50-0.84; $\mathrm{P}=0.01)$ relative to patients with the genotype TT. Male smokers $>60$ years of age with rs3743073G variant genotypes had significantly increased risk of lung cancer $(\mathrm{P}<0.05)$, while female non-smoking patients $\leq 60$ years old with rs $3743073 \mathrm{G}$ variant genotypes had no obvious increased risk of lung cancer ( $\mathrm{P}>0.05)$.

\section{Discussion}

It has been verified in multiple populations that there is a correlation between genetic variation of the nicotine receptor family 
and lung cancer incidence (17-19). Polymorphism rs3743073 $(\mathrm{T}>\mathrm{G})$ of the CHRNA3 gene was the functional genetic variation site of peculiar relevance for the Chinese (22). This case-controlled study on 600 cases of lung cancer revealed a statistically significant difference in genotype frequency rs3743073 (T>G) and allele frequency between lung cancer patients and a normal control population. A significant increase of rs $3743073 \mathrm{G}$ carrier frequency markedly increases the risk of lung cancer and was consistent with the previous results in Chinese population (22). These results indicate a role for this site as a biological susceptibility marker for lung cancer in the Chinese population. There was significant difference in SNP site frequency and haplotype module in $\operatorname{rs} 3743073(\mathrm{~T}>\mathrm{G})$, with no chain relationship with the high contact strength sites of lung cancer reported by previous studies in other ethnic groups. Therefore, greater clarity is needed on whether this site is correlated with lung cancer incidence in other populations.

A number of studies have verified that smoking is closely correlated with lung cancer (3-5). Our study also investigated the correlation of genetic variation of $\operatorname{rs} 3743073(\mathrm{~T}>\mathrm{G})$ and lung cancer incidence between smokers and non-smokers in a cohort. The results demonstrate that rs3743073G increases the risk of lung cancer for smokers but had no marked effect on non-smokers. Simultaneously, multiple studies have found that lung cancer incidence increased with increasing age, and nearly $70 \%$ of primary lung cancer patients were male $(23,24)$. We found that age and gender had interactive effects with variant genotype rs $3743073 \mathrm{G}$; both increase the risk of lung cancer. In conclusion, subjects with the rs $3743073 \mathrm{G}$ variant genotype of the CHRNA3 gene had significantly increased risk of lung cancer, particularly for male smokers over 60 years of age.

\section{Acknowledgements}

This study was supported by the Jiangsu Provincial Health Department (Grant no. Z200902).

\section{References}

1. Jemal A, Siegel R, Ward E, Hao Y, Xu J and Thun MJ: Cancer statistics, 2009. CA Cancer J Clin 59: 225-249, 2009.

2. Chen WQ: Estimation of cancer incidence and mortality in China in 2004-2005. Zhonghua Zhong Liu Za Zhi 31: 664-668, 2009 (In Chinese).

3. Brennan P, Crispo A, Zaridze D, Szeszenia-Dabrowska N, Rudnai P, Lissowska J, Fabiánová E, Mates D, Bencko V, Foretova L, et al: High cumulative risk of lung cancer death among smokers and nonsmokers in Central and Eastern Europe. Am J Epidemiol 164: 1233-1241, 2006.

4. Spitz MR, Hong WK, Amos CI, Wu X, Schabath MR, Dong Q, Shete $\mathrm{S}$ and Etzel CJ: A risk model for prediction of lung cancer. J Natl Cancer Inst 99: 715-726, 2007.

5. Parkin DM, Pisani P, Lopez AD and Masuyer E: At least one in seven cases of cancer is caused by smoking. Global estimates for 1985. Int J Cancer 59: 494-504, 1994.

6. Papi A, Casoni G, Caramori G, Guzzinati I, Boschetto P, Ravenna F, Calia N, Petruzzelli S, Corbetta L, Cavallesco G, et al: COPD increases the risk of squamous histological subtype in smokers who develop non-small cell lung carcinoma. Thorax 59: 679-681, 2004
7. Amos CI, Caporaso NE and Weston A: Host factors in lung cancer risk: a review of interdisciplinary studies. Cancer Epidemiol Biomarkers Prev 1: 505-513, 1992.

8. Lissowska J, Foretova L, Dabek J, Zaridze D, SzeszeniaDabrowska N, Rudnai P, Fabianova E, Cassidy A, Mates D, Bencko V, et al: Family history and lung cancer risk: international multicentre case-control study in Eastern and Central Europe and meta-analyses. Cancer Causes Control 21: 1091-1104, 2010

9. Starek A and Podolak I: Carcinogenic effect of tobacco smoke. Rocz Panstw Zakl Hig 60: 299-310, 2009 (In Polish).

10. Wall JR: Treatment of a habitual smoker using nicotine gum: a case report. Va Dent J 73: 17-19, 1996.

11. West KA, Brognard J, Clark AS, Linnoila IR, Yang X, Swain SM, Harris C, Belinsky S and Dennis PA: Rapid Akt activation by nicotine and a tobacco carcinogen modulates the phenotype of normal human airway epithelial cells. J Clin Invest 111: 81-90, 2003.

12. Saccone SF, Hinrichs AL, Saccone NL, Chase GA, Konvicka K, Madden PA, Breslau N, Johnson EO, Hatsukami D, Pomerleau O, et al: Cholinergic nicotinic receptor genes implicated in a nicotine dependence association study targeting 348 candidate genes with 3713 SNPs. Hum Mol Genet 16: 36-49, 2007.

13. Bierut LJ, Stitzel JA, Wang JC, Hinrichs AL, Grucza RA, Xuei X, Saccone NL, Saccone SF, Bertelsen S, Fox L, et al: Variants in nicotinic receptors and risk for nicotine dependence. Am J Psychiatry 165: 1163-1171, 2008.

14. Minna JD: Nicotine exposure and bronchial epithelial cell nicotinic acetylcholine receptor expression in the pathogenesis of lung cancer. J Clin Invest 111: 31-33, 2003.

15. Tsurutani J, Castillo SS, Brognard J, Granville CA, Zhang C, Gills JJ, Sayyah J and Dennis PA: Tobacco components stimulate Akt-dependent proliferation and NFkappaB-dependent survival in lung cancer cells. Carcinogenesis 26: 1182-1195, 2005.

16. Schuller HM: Is cancer triggered by altered signalling of nicotinic acetylcholine receptors? Nat Rev Cancer 9: 195-205, 2009.

17. Thorgeirsson TE, Geller F, Sulem P, Rafnar T, Wiste A, Magnusson KP, Manolescu A, Thorleifsson G, Stefansson H, Ingason A, et al: A variant associated with nicotine dependence, lung cancer and peripheral arterial disease. Nature 452: 638-642, 2008.

18. Amos CI, Wu X, Broderick P, Gorlov IP, Gu J, Eisen T, Dong Q, Zhang Q, Gu X, Vijayakrishnan J, et al: Genome-wide association scan of tTG SNPs identifies a susceptibility locus for lung cancer at 15q25.1. Nat Genet 40: 616-622, 2008.

19. Hung RJ, McKay JD, Gaborieau V, Boffetta P, Hashibe M, Zaridze D, Mukeria A, Szeszenia-Dabrowska N, Lissowska J, Rudnai P, et al: A susceptibility locus for lung cancer maps to nicotinic acetylcholine receptor subunit genes on $15 \mathrm{q} 25$. Nature 452: 633-637, 2008.

20. Zhang Q, Tang X, Zhang ZF, Velikina R, Shi S and Le AD: Nicotine induces hypoxia-inducible factor-lalpha expression in human lung cancer cells via nicotine acetycholine receptormediated signaling pathways. Clin Cancer Res 13: 4686-4696, 2007.

21. Le Marchand L, Derby KS, Murphy SE, Hecht SS, Hatsukami D, Carmella SG, Tiirikainen M and Wang H: Smokers with the CHRNA lung cancer-associated variants are exposed to higher levels of nicotine equivalents and a carcinogenic tobacco-specific nitrosamine. Cancer Res 68: 9137-9140, 2008.

22. Niu X, Chen Z, Shen S, Liu Y, Zhou D, Zhang J, Li Z, Yu Y, Liao M, Lu S and He L: Association of the CHRNA3 locus with lung cancer risk and prognosis in Chinese Han population. J Thorac Oncol 5: 658-666, 2010.

23. Xing X, Liao Y, Tang H, Chen G, Ju S and You L: Genderassociated differences of lung cancer and mechanism. Zhongguo Fei Ai Za Zhi 14: 625-630, 2011 (In Chinese).

24. Gridelli C, Langer C, Maione P, Rossi A and Schild SE: Lung cancer in the elderly. J Clin Oncol 25: 1898-1907, 2007. 